\title{
ATTACHMENT PLACE : STUDI FENOMENOLOGI SPECIAL PLACE ANAK USIA DINI DI PAUD ISLAM DAN TK ISLAM DI KABUPATEN MALANG
}

\author{
Akhmad Mukhlis \\ (UIN Maulana Malik Ibrahim Malang)
}

\begin{abstract}
Abstrak:
Penelitian ini bertujuan untuk mengetahui kelekatan tempat (attachment place) pada anak usia dini. Berbeda dengan penelitian-penelitian sebelumnya, penelitian ini memfokuskan kajiannya pada tempat-tempat yang dianggap spesial (special place) oleh anak di lingkungan rumah mereka. Metodologi fenomenologi dipilih untuk mengeksplorasi tujuan penelitian dalam dua tahap. Tahap pertama dilakukan di sekolah dengan mendiskusikan buku dengan 13 peserta didik. Tiga anak yang paling aktif dan mampu berkomunikasi dengan baik diminta untuk menjadi partisipan pada tahap kedua yaitu kunjungan rumah. Dua tahapan penggalian data menemukan bahwa anak-anak memiliki banyak tempat yang dianggap spesial. Keberadaan tempat-tempat tersebut biasa digunakan untuk bersembunyi, meredakan emosi, bermain dan mengembangkan rasa otonomi diri.
\end{abstract}

Kata Kunci: Attachment Place, Special Place, Anak Usia Dini, Otonomi Diri.

\begin{abstract}
:
This study aims to determine the attachment point (attachment place) in early childhood. In contrast to previous studies, this research focusing on places that are considered special (special place) by children in their home environment. Phenomenological methodology chosen to explore the purpose in two phases. The first phases conducted in school by discussing the book with 13 learners. Three children were the most active and able to communicate well be asked to be a participant in the second stage of the home visit. Two stages of extracting data found that children have a lot of places that are considered special. The existence of these places used to hide, defuse emotions, play and develop a sense of self autonomy.
\end{abstract}

Keywords: Attachment Place, Special Place, Early Childhood, Self Autonomy. 


\section{A. Pengantar}

Tempat (place) merupakan bagian dari lingkungan yang telah mendapatkan klaim dari emosi manusia. ${ }^{1}$ Bahwa sebuah tempat dapat mempengaruhi performa manusia adalah sesuatu yang sudah sangat jamak kita dengar dan kita percayai. Namun jenis tempat seperti apakah yang mempengaruhi manusia, hal tersebut adalah pertanyaan klasik yang terus membutuhkan penelitian, mengingat setiap tempat memiliki karakteristik yang berbeda dalam ranah personal seseorang. ${ }^{2}$ Hal tersebut berarti kadar "spesial" setiap tempat berbeda antara satu orang dengan orang lainnya.

Bagi anak, tempat-tempat spesial membuat jalur khusus ke dunia psikologis mereka. ${ }^{3}$ Tempat spesial merupakan ruang dimana anak-anak mengukir dunianya dengan melakukan klaim sebuah tempat sebagai milik mereka sendiri. ${ }^{4}$ Berbagai penelitian sebelumnya menemukan beberapa tempat spesial bagi anak, yaitu tempat favorit, tempat persembunyian, ruang rahasia dan juga tempat-tempat saat momen bahagia. ${ }^{5}$ Tempat-tempat spesial tersebut turut membentuk kualitas hidup seseorang saat mereka dewasa ${ }^{67}$ sehingga memberikan informasi yang berguna tentang bagaimana anak-anak mengembangkan pengalaman, preferensi, dan perasaan mereka.

Kajian tentang tempat dalam psikologi merupakan kajian yang melibatkan aspek kognitif dan emosional seseorang yang turut membentuk identitas manusia, atau biasa disebut dalam kajian place identity. ${ }^{8}$ Anak-anak mengembangkan hubungan yang unik dengan semua tempat dalam berbagai dimensi kehidupan mereka. Apakah di sekolah, di rumah, dalam kehidupan pribadi atau sosial, anak-anak mulai membedakan tempat didasarkan pada perasaan dan atau pengalaman mereka saat berinteraksi. Anak merupakan agen aktif yang menciptakan pengalamannya sendiri tentang tempat mereka di dunia.

${ }^{1}$ D. Sobel,. Children's Special Places: Exploring the Role of Forts, Dens, and Bush Homes in Middle Childhood (Detroit: Wayne State University, 2002).

2 J. Ellis. "The Significance of Place in the Curriculum of Children's Everyday Lives." Taboo: The Journal of Culture and Education 8(1) (2004): 23-42.

3 C. Green. "A Place of My Own: Exploring Preschool Children's Special Places in the Home Environment," Children, Youth and Environments 21(2), (2011).

4 Green. "A Place of My Own."

5 L. Chawla. "Ecstatic Places. Children's Environments Quarterly" 7(4) (1990): 18-23.

${ }^{6}$ D. Sobel. "Children's Special Places."

7 Chawla. "Ecstatic Places. Children's Environments," 18-23.

8 J. Tunner. "Special Place: Place Attachment and Children's Happiness," Primary Geographer (2009): 1-8. 
Penelitian ini bermaksud untuk membuktikan hal tersebut. Penting bagi para pengasuh untuk menyadari dan memberi ruang terhadap hak partisipatif anak tentang apa yang penting bagi mereka, terutama saat mereka belajar. Pendidikan anak selayaknya mempertimbangkan hal-hal yang penting bagi anak dan juga ekspresi mereka melalui interaksinya dengan lingkungan fisik dan sosial.

Chawla menjelaskan bahwa studi tentang tempat pada masa anak-anak sangat penting, karena hal tersebut berkontribusi pada kualitas kehidupan seseorang sekarang. ${ }^{9}$ Beberapa penelitian telah memfokuskan kajiannya pada tempat-tempat anak-anak, dalam berbagai disiplin ilmu, mulai pendidikan, psikologi, arsitektur, geografi, dan studi lingkungan. Dimulai Hart dengan fokus penelitian pada pengalaman anak terhadap tempat, garis panjang penelitian telah difokuskan pada pemahaman perspektif tempat anak-anak, dengan minat khusus di tempat-tempat spesial. ${ }^{10}$

Setiap dari kita memiliki tempat-tempat spesial yang kita anggap mampu meningkatkan emosi positif. Seperti sungai, pantai, ruangan belajar, perpustakaan, taman dan lainnya. Oleh karea itu saya menjadi tertarik untuk mempelajari tempat pengalaman pada masa anak-anak. Dalam meninjau literatur, tampaknya terdapat celah dalam studi tempat spesial anak-anak. Tempat masa kecil telah diteliti melalui kenangan dewasa,11 lingkungan luar masa anak pertengahan, 12 sekolah anak usia dini dan pengaturan tempat penitipan anak, serta tempat spesial anak di rumah. ${ }^{13}$

Bagaimana anak membangun dan memaknai sebuah tempat sangat penting untuk dipertimbangkan dalam pengasuhan dan pendidikan, terutama saat kita mengenalkan mereka dengan tempat baru seperti sekolah. Oleh karena itu kita harus mampu memahami arti tempat dalam kehidupan anak-anak.

Penelitian ini merupakan penelitian tindak lanjut dari penelitianpenelitian tentang anak dan tempat (place). Beberapa penelitian sebelumnya telah mendeskripsikan kelekatan anak dengan tempat (attachment place) namun dengan seting yang berbeda-beda. Kelekatan tempat anak usia dini dengan ruang sekolah dan penitipan anak telah diteliti oleh Skånfors, Löfdahl, \& Hagglund. Chawla telah juga meneliti tempat spesial waktu masa kanak-kanak pada orang dewasa. ${ }^{14}$ Tempat spesial di lingkungan di luar sekolah juga telah diteliti oleh

\footnotetext{
${ }^{9}$ Chawla. "Childhood Place Attachments,"63-86.

${ }^{10}$ R. Hart. Children's Experience of Place (New York: Irvington Publishers, 1979).

${ }^{11}$ Chawla. "Childhood Place Attachments,"63-86.

12 D. Sobel. "Children's Special Places."

13 Green. "A Place of My Own."

${ }^{14}$ L. Chawla. "Childhood Place Attachments," In Altman, I. and S. Low, ed. Place Attachment (New York: Plenum, 1992), 63-86.
} 
Hart dan Sobel.15 16 Yang terakhir adalah penelitian Green tentang tempat spesial anak di rumah. ${ }^{17}$ Penelitian ini merupakan langkah ilmiah untuk melanjutkan rangkaian penelitian diatas, terutama tempat spesial dalam seting rumah namun dalam konteks budaya Indonesia, terutama masyarakat Kota Malang.

\section{B. Mendefinisikan Tempat (Place and Placeness)}

Secara umum tempat dapat didefinisikan sebagai daerah atau ruangan yang dibutuhkan manusia untuk melakukan aktivitas kehidupannya. ${ }^{18}$ Jika kita menggunakan definisi tersebut, maka apabila di sekolah tempat dapat menjadi seluruh sekolah, ruang kelas, atau bahkan kursi tertentu. Apapun yang digunakan manusia dalam sekolah tersebut adalah tempat. Bagaimana kita membedakan antara ruangan dan tempat? Ruang otomatis akan menjadi sebuah tempat ketika ruangan telah mengandung bobot makna oleh mereka yang menghabiskan waktu di dalamnya. Artinya terdapat aspek memori dan pengalaman yang membedakan ruang dan tempat. Hal tersebut dengan penjelasan Relph yang menyebut tempat sebagai sebuah wilayah makna dari ruangan. Dari definisi tersebut, maka kita dapat menyimpulkan bahwa segala sesuatu di semesta adalah ruang, namun tidak semuanya adalah tempat sebelum ada manusia yang menggunkannya dan menyimpannya dalam struktur kesadaran mereka melalui memori.

Pendefinisian tempat diatas akan membawa konsekuensi tertentu dalam konsep "placeness". Placeness merupakan ciptaaan subjektif atau intersubjektif dari setiap orang dari sebuah tempat, sehingga hanya akan dipahami dan dirasakan oleh orang tersebut. ${ }^{19}$ Sebagai guru, ketika kita berpikir tentang respon yang diberikan kepada kita dan kita berusaha untuk memahami seberapa paham mereka tentang materi yang kita sampaikan saat itu. Seperti itulah placeness bermain dalam ranaah kognitif seorang guru yang secara laangsung ataupun tidak akan berpengaruh kepada gaya mengajar guru dan gaya evaluasi mereka.

15 D. Sobel. "Children's Special Places.”

16 Hart, R. "Children's Experience of Place."

17 Green. "A Place of My Own."

18 P. Brey. "Space-shaping technologies and the geographical disembedding of place" In A. Light and J.M. Smith (Ed.), Philosophy and geography III: Philosophies of place (Lanham, MD: Rowman \& Littlefield, 1998), 239-263.

19 J. Smith, M., Light, A., \& Roberts, D. “Introduction: Philosophies and geographies of place," In A. Light \& J. M. Smith (Ed.), Philosophy and geography III: Philosophies of place (Lanham, MD: Rowman \& Littlefield, 1-13), 1-13. 
Keterangan diatas menjelaskan kepada kita bahwa tempat merupakan sesuatu yang dinamis dan berubah. Tempat lebih dari sekedar lokasi dalam ruangan fisik, namun juga memainkan aspek kognitif-emosional yang mempengaruhi pengalaman dan aktivitas seseorang. Tempat dengan demikian bermain sangat signitifikan terhadap "cara" manusia berperilaku. Ashcroft menyebut dinamika tempat seperti berkembangnya wacana dalam sebuah diskursus tertentu. Tempat adalah sebuah hasil dari huni, sebuah konsekuensi dari bagaimana cara manusia menghuni ruang. Dengan demikian, jika kita mencoba memahami kelas sebagai sebuah tempat maka kelas bukanlah semata sebuah bangunan, kursi, meja, papan dn lainnya, melainkan sebagai sebuah pengalaman yang dihasilkan dari cara seseorang menghuni bangunan sekolah yang sangat dipengaruhi oleh identitas yang terbentuk di tempat lain sebelumnya.

\section{Identitas Tempat (Place Identity)}

Tempat (place) merupakan konsep yang rumit untuk di analisis. Hal ini dikarenakan kompleksnya aspek-aspek dari suatu tempat. Namun demikian, berdasarkan literatur-literatur yang ada secara luas dipahami bahwa tempat adalah suatu ruang yang memiliki makna tertentu bagi penghuni atau penggunanya. Konsep place didasarkan pada interaksi antara seseorang, seting fisik, dan aktivitas yang terjadi pada lokasi tersebut. Beberapa tempat dianggap lebih penting dibanding tempat lain karena atribut-atribut fisik yang dimilikinya dan karena jenis-jenis aktivitas yang terjadi pada tempat tersebut.

Hubungan antara tempat (place) dan identitas (identity) dapat dipahami melalui beberapa pendekatan yang berbeda. Namun demikian, mengingat luasnya cakupan konsep tempat, maka sampai saat ini belum ada penjelasan yang merupakan konsensus tentang hubungan antara kedua konsep tersebut. Dalam konteks psikologi sosial, Breakwell mengembangkan "model proses identitas". Model dari Breakwell mengemukakan empat prinsip identitas: selfesteem, self-efficacy, distinctiveness, dan continuity. Dalam konteks tersebut dapat digambarkan bahwa lingkungan memainkan peran dalam dinamika identitas; bahwa keempat prinsip tersebut berhubungan dengan tempat (place); dan bahwa prinsip-prinsip yang berbeda nampaknya diperlakukan berbeda pula oleh setiap individu.

Self-esteem didefinisikan sebagai suatu evaluasi diri atau kelompok yang positif dengan mana seseorang mengidentifikasikan diri. Beberapa penelitian yang telah dilakukan menunjukkan bahwa evaluasi personal terhadap lingkungan lokal dan evaluasi positif terhadap lingkungan tersebut oleh orang lain menghasilkan kebanggaan, dan oleh karenanya memberikan kontribusi 
terhadap self-esteem. Lalli menunjukkan pentingnya hidup atau bertempat tinggal di tempat-tempat bersejarah dalam membentuk self-esteem.

Self-efficacy didefinisikan sebagai kemampuan seseorang untuk berfungsi secara tepat dalam lingkungan fisik dan situasi sosial tertentu yang dihubungkan dengan kebutuhan manusia untuk mengendalikan lingkungan. ${ }^{20}$ Prinsip lain dalam konsep identitas adalah distinctiveness, yaitu keinginan untuk memelihara keberbedaan dari yang lain.

Distinctiveness berhubungan dengan persepsi positif terhadap keunikan suatu tempat, dan pemanfaatan tempat yang berbeda dengan orang lain pada kawasan lain di kota tersebut. Distinctiveness ini menyebabkan seseorang mempunyai hubungan khusus antara dirinya dengan lingkungan huniannya, yang secara jelas berbeda dengan jenis hubungan yang lain. ${ }^{21}$ Identitas tersebut dengan teritori tertentu menyebabkan pengidentifikasian seseorang dengan orang-orang lain yang hidup dalam ruang tersebut.

Identitas juga mensyaratkan adanya kebutuhan untuk keberlanjutan (continuity) dalam konteks waktu dan situasi. Twigger-Ross \& Uzzell mengemukakan dua bentuk kontinuitas dalam hubungan dengan lingkungan, yaitu:

1. The place-referent continuity, yaitu apabila tempat (place) bertindak sebagai acuan masa lalu dan tindakan sehingga menghasilkan hubungan antara identitas masa lalu dengan identitas masa kini.

2. The place-congruent continuity, yaitu ketidak serasian antara lingkungan dan keinginan serta nilai-nilai masyarakat setempat. ${ }^{22}$

\section{Kelekatan Terhadap Tempat (Place Attachment)}

Kita akan menemui kesulitan untuk mendefinisikan kelekatan pada tempat jika kita melihat betapa luasnya studi tentang ini pada tingkatan teoritis maupun empiris. Terdapat banyak istilah yang mirip dan terkadang seperti sinonim dari place attachment seperti community attachment, sense of community, place attachment, place identity, ${ }^{23}$ place dependence, ${ }^{24}$ sense of place ${ }^{25}$

20 R. B. Riley. "Attachment to the Ordinary Landscape." In I. Altman and S.M. Low, ed. Place Attachment (New York: Plenum Press, 1992), 13-35.

21 M. Uljens, "On the philosophical foundation of phenomenography," In G. Dall'Alba \& B. Hasselgren (Ed.), Reflections on Phenomenography (Goteborg: Acta Universitatis Gothenburgensis, 1996), 105-130.

22 Uljens, "On the philosophical foundation of phenomenography," 105-130.

${ }^{23}$ H. M. Proshansky dan Fabian, A.K. "The Development of Place Identity in the Child." In Weinstein, Carol S. and Thomas G. David, ed. Spaces for Children: The Built Environment and Child Development (New York: Plenum Press, 1987), 21-40. 
dan masih banyak istilah lainnya. ${ }^{26}$ Beberapa istilah tersebut membuat kita kesulitan untuk mengatakan apakah kita berbicara tentang konsep yang sama namun dengan nama yang berbeda atau sebaliknya konsep berbeda dengan nama yang sama. Namun jika secara umum, terdapat konsensus yang menyatakan bahwa kelekatan terhadap tempat merupakan ikatan afektif (emosional) antara seseorang dengan tempat yang cenderung menetap dan berhubungan dengan keamanan dan kenyamanan. Hal tersebut hampir sama dengan pendefinisian yang dilakukan Taylor yang menyatakan kelekatan terhadap tempat adalah ikatan emosional yang bersifat positif antara individu dengan tempat. Waideman dan Anderson menyatakan ikatan emosional tersebut bukan hanya bersifat positif, namun juga bersifat negatif. Namun kemudian banyak peneliti lain seperti Hummon dan Low menyatakan kelekatan terhadap tempat sebagai sebuah ikatan kognisi dan emosional yang melibatkan tempat dan kebanyakan bersifat positif. ${ }^{27} 28$

Place attachment pada dasarnya mengacu pada terbentuknya ikatan batin seseorang dengan suatu tempat, misalnya lingkungan hunian/rumah, sekolah, tempat bermain dan lainnya. Ikatan batin yang merupakan kelekatan dan kecintaan terhadap lingkungan hunian secara positif akan memberikan rasa aman, nyaman, tentram, yang pada gilirannya akan mermberikan kesejahteraan dan kebahagiaan bagi seseorang dalam menjalankan. Sebaliknya, tidak adanya kelekatan terhadap tempat (place attachment) dapat menimbulkan perasaan terasing dari lingkungannya, rasa tidak betah/ tidak kerasan di lingkungannya, yang pada gilirannya akan memberikan dampak buruk secara psikologis pada seseorang. Apabila kondisi seperti ini berlangsung terus menerus dapat berdampak buruk bagi kesejahteraan hidup manusia.

\section{E. Metodologi}

Penelitian ini merupakan studi kualitatif interpretatif dengan pendekatan fenomenologi, dimana peneliti tertarik memahami bagaimana subjek membuat makna dari situasi atau fenomena. Peneliti dalam kualitatif bertindak sebagai

${ }^{24}$ F. Marton. "Phenomenography - Describing Conceptions of the World Around Us," Instructional Science, 10, (1981): 177-200.

25 D. M. Hummon. "Community Attachment: Local Sentiment and Sense Of Place." In: Altman, I. and Low, S., ed. Place Attachment (New York, NY: Plenium Press, 1992), 314.

${ }^{26}$ M.C. Hidalgo dan Hernandez, B. "Place Attachment: Conceptual and Empirical Questions." Journal of Environmental Psychology 21(2001): 273-281.

27 Hummon. "Community Attachment: Local," 314.

${ }^{28}$ I. Altman dan Low, S.M. Place Attachment (New York: Plenum Press, 1992).

Jurnal Pendidikan Agama Islam

Volume 4 Nomor 1 Mei 2016

ISSN(p) 2089-1946\& ISSN(e) 2527-4511

Hal. 140 - 156 
mediator atau instrument inti penelitian. Metode penelitian kualitatif adalah metode penelitian yang digunakan untuk meneliti pada kondisi obyek yang alamiah (natural setting) dimana peneliti adalah sebagai instrument kunci.

Secara khusus, saya akan mengarahkan minat pada tempat spesial anak usia dini melalui pengalaman mengajar guru PAUD/TK dan mengamati anak saya sendiri saat mengembangkan perilaku dan preferensi tertentu tentang sebuah tempat. Hal tersebut peneliti lakukan mengingat koneksi awal anak dengan tempat memainkan peran penting dalam perkembangannya. ${ }^{29}$ Hal tersebut mendorong peneliti untuk belajar lebih banyak tentang bagaimana anak-anak membangun pengalaman dengan tempat di lingkungan rumah. Dalam sebuah studi interpretatif terutama yang melibatkan anak-anak adalah penting untuk mengenali dan memahami ketidakseimbangan, bias dan subjektivitas informasi antara peneliti (usia dewasa) dan subjek anak (fase anak). Oleh karena itu selama penelitian, peneliti terus berupaya untuk menyisihkan pemahaman pribadi dan perasaan subjektif terkait tempat dan menggunakan mata dan pengalaman subjek (anak-anak) tentang makna tempat.

Pengalian data dalam penelitian ini dilakukan dalam dua tahapan, tahap pertama dilakukan di sekolah PAUD. Tahap ini peneliti menggunakan metode Focus Group Discussion yang melibatkan peserta didik, guru dan juga pengasuh/orangtua peserta didik. Diskusi diarahkan pada minat anak-anak pada ruangan tertentu dan juga representasinya menggunakan sarana buku bergambar dengan seting ruangan rumah dengan tema "tempat favoritku". Pada tahap kedua peneliti melakukan kunjungan ke rumah anak-anak yang terlibat secara aktif dalam tahap pertama dan mendapatkan dukungan dari orangtua mereka. Tahap ini menggunakan wawancara terbuka (semi-informal) terkait minat terkait tempat-tempat spesial bagi anak.

\section{F. Paparan Data}

\section{Tahap Pertama}

Pada tahapan pertama penggalian data, peneliti menganalisis data FGD dengan melakukan kategori data menggunakan metode analisis phenomenographic untuk melihat karakteristik tempat spesial anak berdasarkan media buku bergambar "tempat favoritku". Media buku bergambar membantu kategorisasi kemungkinan interpretasi makna berbeda yang dilakukan anakanak.

Dari 13 partisipan, secara umum anak-anak menyebutkan bahwa tempat yang mereka sukai adalah tempat yang berada dalam ruangan. Hal tersebut

${ }^{29}$ Chawla. "Childhood Place Attachments," 63-86. 
memiliki kemungkinan hubungan dengan aktivitas partisipan yang sangat minim di luar ruangan. Berikut adalah tabel yang kami turunkan dari data buku cerita subjek:

Tabel 1. Identifikasi tempat spesial dari buku "tempat favoritku"

\begin{tabular}{|c|c|c|}
\hline No & Tipe Tempat Spesial & Jumlah Anak \\
\hline 1 & Setting & \\
\hline & \begin{tabular}{l|l} 
a & Dalam ruangan (Indoor)
\end{tabular} & 13 \\
\hline & \begin{tabular}{l|l|} 
b & Luar ruangan (outdoor) \\
\end{tabular} & 8 \\
\hline \multicolumn{2}{|c|}{ Jumlah } & 21 \\
\hline 2 & Lokasi & \\
\hline & a $\quad$ Rumah & 13 \\
\hline & \begin{tabular}{l|l} 
b & Sekolah
\end{tabular} & 7 \\
\hline & \begin{tabular}{l|l} 
c & Imajinasi/ Tidak nyata
\end{tabular} & 2 \\
\hline \multicolumn{2}{|c|}{ Jumlah } & 22 \\
\hline \multirow[t]{9}{*}{3} & Tempat Spesial Indoor & \\
\hline & Kamar tidur & 5 \\
\hline & Ruang tamu & 3 \\
\hline & Ruang keluarga & 2 \\
\hline & Belakang pintu & 7 \\
\hline & Diantara meja-kursi & 3 \\
\hline & Kamar Mandi & 1 \\
\hline & Dapur & 1 \\
\hline & Dibawah tempat tidur & 5 \\
\hline \multicolumn{2}{|c|}{ Jumlah } & 27 \\
\hline \multirow[t]{4}{*}{4} & Tempat special outdoor & \\
\hline & Teras & 1 \\
\hline & Halaman depan rumah & 2 \\
\hline & Halaman belakang rumah & 5 \\
\hline \multicolumn{2}{|c|}{ Jumlah } & 8 \\
\hline
\end{tabular}

Meskipun partisipan berjumlah 13 anak, namun tempat spesial yang disebutkan berjumlah 21 lokasi yaitu 13 lokasi disebutkan berada pada dalam ruangan dan 8 lokasi berada pada luar ruangan. Hal ini berkaitan dengan banyaknya kesempatan yang diberikan oleh orangtua untuk bermain di dalam ruangan. Semua anak menyebutkan memiliki tempat spesial di dalam area rumah (sebanyak 13 lokasi), sebagian lagi juga menyebutkan sekolah (7 lokasi) dan tempat yang sulit untuk didefinisikan sebanyak 2 lokasi. Data tersebut 
berarti bahwa semua anak memiliki hubungan yang cukup baik dengan rumah tinggalnya.

Belakang pintu merupakan tempat yang paling banyak disukai oleh anak ketika bermain dalam ruangan (yaitu sebanyak 7), diikuti daerah di dalam kamar tidur dan di bawah tempat tidur (masing-masing disebutkan 5 kali), ruang tamu dan area antara meja dan kursi sama disebutkan sebanyak 3 kali, ruang keluarga sebanyak 2 kali dan dapur serta kamar mandi hanya disebutkan masing-masing sebanyak 1 kali.

Data diatas sekaligus juga menyatakan bahwa anak-anak yang menjadi subjek penelitian lebih sering bermain dalam ruangan, hal tersebut disebabkan oleh banyak hal. Hamper kesemua orangtua menyatakan bahwa hal tersebut diakibatkan oleh terbatasnya area luar ruangan dan terbatasnya waktu orangtua untuk mengawasi secara penuh anak-anak yang berada di luar rumah. Beberapa lokasi yang disebutkan diatas membawa anaak-anak pada perasaan-perasaan yang berbeda jika mereka diminta untuk mengungkapkan perasaan mereka terhadap tempat-tempat tersebut. Berikut adalah tabel yang menjelaskan perasaan serta atribut yang biasanya digunakan oleh anak-anak ketika berada dalam tempat favorit mereka:

Tabel 2. Atribut tempat spesial dari buku "tempat favoritku"

\begin{tabular}{|l|l|l|l|}
\hline No & \multicolumn{2}{|c|}{ Atribut Tempat Spesial } & Jumlah Anak \\
\hline 1 & \multicolumn{2}{|l|}{ Perasaan } & \\
\hline & a & "seperti”... & 8 \\
\hline & b & $\begin{array}{l}\text { Ungkapan suhu (hangat/dingin } \\
\text { dan lainnya) }\end{array}$ & 3 \\
\hline & c & Merasa nyaman & 10 \\
\hline & d & Merasa ada yang menemani & 2 \\
\hline Jumlah & 23 \\
\hline 2 & \multicolumn{2}{|l|}{ Teman bermain di tempat spesial } & \\
\hline \multicolumn{2}{|l|}{ a } & Saudara & 2 \\
\hline & b & Orangtua & 8 \\
\hline & c & Kakek/nenek & 5 \\
\hline & d & Teman & 3 \\
\hline & e & Tidak ada & 7 \\
\hline Jumlah & 25 \\
\hline 3 & Barang di tempat special & \\
\hline & A & Mainan & 11 \\
\hline & B & Makanan & 2 \\
\hline & C & Perlengkapan tidur & 1 \\
\hline
\end{tabular}




\begin{tabular}{|l|l|l|l|}
\hline & D & Lainnya & 3 \\
\hline \multicolumn{2}{|l|}{ Jumlah } & 17 \\
\hline 4 & \multicolumn{2}{|l|}{ Aktivitas yang dilakukan } & \\
\hline & & Bersembunyi & 5 \\
\hline & & Bermain dengan mainan & 9 \\
\hline & & Makan & 2 \\
\hline & & Mewarnai/menggambar & 1 \\
\hline Jumlah & 17 \\
\hline
\end{tabular}

Tabel diatas menjelaskan bahwa anak-anak merasa nyaman dan merasa aman ketika mereka berada pada tempat-tempat yang mereka sukai (sebanyak 10 kali diungkapkan), sebagian dari mereka juga menyatakan bahwa tempattempat tersebut dirasakan seperti sesuatu yang mereka senangi (sebanyak 8 kali diungkapkan). Selain itu mereka juga merasakan suhu (3 kali diungkapkan) dan 2 ungkapan lainnya mereka merasa sendirian atau tidak dilihat oleh orang lainnya.

Saat anak-anak membutuhkan teman bermain, sebagian besar dari mereka bermain ditemani oleh orangtua mereka ( 8 anak) saat mereka berada pada tempat spesial mereka, kakek/nenek ( 5 anak), 3 anak bersama teman dan 2 anak lainnya bersama saudara mereka. Data tersebut menunjukkan bahwa subjek penelitian sebagian besar hidup dan diasuh dengan orangtua dan juga beberapa diantaranya hidup bersama kakek/neneknya.

Tempat spesial dari tabel diatas juga mengungkapkan bahwa kegiatan yang dilakukan anak-anak adalah bermain, Karena sebagian besar barang yang dibawa anak-anak ke dalam area tempat spesial adalah mainan. Selain bermain, anak-anak juga menggunakan tempat spesial mereka untuk bersembunyi.

\section{Tahap Kedua}

Tahap ini merupakan tahap kunjungan ke rumah. Kunjungan ke rumah dilakukan pada 3 anak dengan kesepakatan orangtua masing-masing. Kunjungan dirumah pertama-tama menempatkan anak-anak berbicara sambal mengeksplorasi tempat spesial mereka. Peneliti meminta subjek untuk bersamasama bersafari ke tempat spesial mereka sambil melakukan wawancara kepada subjek. Peneliti tidak selalu menggunakan perekam namun juga menggunakan catatan lapangan yang bersifat analitik untuk mencatat hal-hal yang dianggap penting. ${ }^{30}$ Catatan analitik adalah catatan dengan memasukkan kategori

${ }^{30}$ Saldana, J. The Coding Manual for Qualitative Researchers (Los Angeles: Sage, 2009). 
tambahan dari catatan lapangan, hasil wawancara, dan observasi dengan tujuan mencari pola yang muncul dari sumber data.

Selama kunjungan ke lapangan, peneliti menemukan sub kategori dari catatan analitik yang melibatkan anak dengan tempat spesial mereka, yaitu:

1. Anak-anak memiliki banyak tempat spesial

2. Belakang pintu merupakan tempat spesial yang umum

3. Tempat spesial secara teritori merupakan tempat yang tidak luas

4. Kebanyakan anak bersembunyi di tempat spesial

Anak-anak juga menggunakan tempat spesial sebagai tempat untuk bermain dan menyimpan mainan.

\section{G. Diskusi}

Rasa Otonomi (A Sense of Autonomy)

Ahli psikologi terkemuka Erikson menyebutkan bahwa untuk mencapai perkembangan emosi yang sehat, penting bagi setiap anak memperoleh memperoleh rasa otonomi. ${ }^{31}$ Apakah tempat mereka besar atau kecil, rahasia atau mengungkapkan, bersama atau pribadi, outdoor atau indoor, tempat bermain atau tempat pengungsian, tampaknya ada rasa otonomi di semua pengalaman anak-anak dari tempat-tempat spesial mereka.

Penelitian ini menunjukkan betapa anak-anak sangat bersemangat menunjukkan tempat yang menurut mereka sangat spesial saat di rumah dan orang tua mereka mengonfirmasi informasi tersebut saat peneliti melakukan wawancara pada langkah terakhir tahap kedua penelitian. Hal tersebut menunjukkan bahwa tempat yang dianggap spesial bagi anak di rumah merupakan ruang yang digunakan anak untuk menunjukkan control penuh atas kehendak mereka. Aktivitas seperti mendesain ruangaan, menempatkan mainan dalam tempat tersebut serta memberikan atribut-atribut khusus merupakan contoh rasa control yang dilakukan anak untuk menunjukkan otonomi mereka terhadap tempat tersebut.

Pada sebagian anak yang hidup dalam rumah orangtua mereka sendiri, mereka lebih bebas memilih ruang atau lokasi untuk dijadikan tempat spesial. Namun beberapa orangtua membatasi aktivitas anak-anak mereka mengeksplorasi ruangan untuk memilih lokasi yang dijadikan "markas" tempat spesial mereka. Alasan mereka beragam, mulai dari kebersihan, keselamatan sampai kesehataan.

Secara keseluruhan, anak-anak cenderung memilih sendiri tempat yang mereka anggap sebagai tempat spesial meskipun beberapa orangtua

${ }^{31}$ Erik H. Erikson. Childhood and Society (New York: Norton, 1950). 
menyarankan ruangan lainnya. Fakta tersebut membuktikan bahwa tempattempat spesial memberikan anak-anak dua kesempatan secara langsung untuk berpikir dan bertindak seperti yang mereka inginkan. Kesempatan untuk berpikir dan bertindak sesuai dengan keinginan dan fantasi mereka inilah yang kemudian mampu mengembangkan rasa individualitas selama tahun-tahun prasekolah.

\section{Anak memiliki banyak pilihan tempat}

Selama tahapan kedua, saat subjek memandu peneliti menunjukkan tempat-tempat spesial mereka, anak-anak menunjukkan tempat yang lebih banyak daripada yang mereka ungkapkan di sekolah. Peneliti diajak berputar mulai dari ruang tamu, kamar tidur, ruang keluarga, depan kamar mandi, depan rumah dan dapur. Dari tahapan tersebut peneliti menemukan bahwa anak-anak tidak mampu mendeskripsikan ruangan secara spesifik tanpa berda dalam situasi langsung. Konsistensi penyebutan lokasi saat di sekolah dan di rumah juga kebanyakan berbeda, ini dikarenakan anak-anak pra sekolah belum menguasai konsep bahasa seperti tahapan usia diatasanya.

Berikut adalah beberapa tempat spesial dalam ruangan yang telah disebutkan dalam tabel 4.1. diatas:

1. Di balik pintu

2. Kamar tidur

3. Di bawah tempat tidur

4. Ruang tamu

5. Diantara meja dan kursi

6. Ruang keluarga

7. Dapur

8. Kamar mandi

\section{Di balik Pintu}

Tempat di balik pintu merupakan tempat yang paling banyak dirujuk anak-anak untuk menyebutkan tempat spesial mereka. Beberapa menunjuk di balik pintu kamar mereka dan sebagian besar lainnya yang belum memiliki kamar menunjuk pintu kamar orangtua mereka dan pintu kamar ruang tamu. Bebrapa orangtua menyebutkan bahwa anak-anak mereka menyukai berada di balik pintu untuk bersembunyi terhadap mereka, beberapa yang lainnya juga menambahkan bahwa tempat di balik pintu merupakan tempat yang sangat jarang diakses oleh mereka (orang dewasa). Hal tersebut ditambah dengan beberapa kebiasaan tata ruang yang menempatkan gantungan baju di balik pintu kamar. Anak-anak pada dasarnya menyukai hal-hal dimana mereka merasa bebas dan tidak terlihat oleh 
orang dewasa saat melakukan aktivitas yang mereka sukai. Hal tersebut sejalan dengan penemuan Gillespie (2006) yang menyebutkan bahwa anak-anak mendapatkan privasi dari tempat-tempat yang terkesan tersebunyi dan jauh dari perhatian orang dewasa.

\section{Kamar Tidur}

Berdasarkan temuan studi masa lalu dapat dijelaskan bahwa kamar tidur adalah salah satu tempat yang dianggap spesial yang umum untuk anak-anak prasekolah. Schiavo menyebut kamar tidur sebagai "pusat kehidupan seharihari". Di kamar tidur, anak-anak tidak hanya menyimpan barang-barang mereka, mereka juga menemukan ruang untuk sendirian atau bermain. Kamar tidur menciptakan ruang pribadi untuk anak-anak di mana mereka memiliki rasa yang lebih besar dari kontrol atas kegiatan dan objek. ${ }^{32}$ Penelitian ini juga menunjukkan bahwa ada tempat-tempat kecil dalam kamar tidur anak-anak yang dianggap spesial bagi mereka. Dalam kamar tidur, anak-anak data mengidentifikasikan beberapa benda untuk atribut bermain, seperti lemari bantal, guling, meja dan juga di bawah tempat tidur.

Dalam penelitian ini kamar tidur tidak menjadi pilihan utama anak-anak, bukan Karena model identifikasi anak berbeda pada tiap budaya, melainkan kebanyakan subjek yang berpartisipasi dalam penelitian ini belum memiliki kamar tidur sendiri. Selain lahan rumah yang diantaranya tidak memadai, kebanyakan orangtua juga belum tega untuk memisahkan kamar anaknya dengan kamar mereka.

\section{Tempat Berukuran Kecil}

Pada usia dini, anak-anak memiliki kontrol terbatas atas akses dewasa untuk hal-hal dan ruang mereka. ${ }^{33} 34$ Mungkin ini sebabnya beberapa tempat khusus anak-anak berukuran kecil. Atau mungkin tempat-tempat spesial dipilih anak-anak karena beberapa tempat menawarkan hal yang bagus untuk bersembunyi. Ketika ditanya mengapa tempat tersebut sangat mereka sukai dan mereka gunakan beraktivitas keseharian, anak-anak hanya bisa menjawab bahwa mereka hanya menyukainya saja. Meskipun alasan yang mereka ungkapkan sangat sederhana, banyak penelitian mengungkapkan hal yang serupa, bahwa anak-anak memilih tempat yang sangat kecil atau sempit untuk dijadikan sebagai tempat utama yang mereka sukai.

32 Proshansky. "The Development of Place Identity," 21-40.

33 Proshansky. "The Development of Place Identity," 21-40.

34 A. Hunter. "Persistence of Local Sentiments In Mass Society," In: Street, D., ed. Handbook of Contemporary Urban Life (San Francisco, CA: Jossey-Bass, 1978), 741. 
Terbatasnya ukuran (kecil) memungkinkan anak-anak untuk mampu mengontrol dengan penuh tempat tersebut. Ukuran fisik dan jangkauan anak yang juga kecil, memungkinkan mereka untuk melakukan efisiensi waktu dan tenaga untuk mengontrol tempat yang berukuran kecil. Ukuran yang kecil juga memungkinkan mereka untuk membuat regulasi sesuai dengan keinginan mereka. Sebagai contoh, dengan luas yang sempit anak-anak akan mudah untuk menerapkan aturan bagi orang-orang disekitarnya (terutama orangtua) untuk tidak memasuki tempat spesial mereka.

\section{Tempat Bersembunyi}

Tampaknya terdapat hubungan yang umum antara tempat spesial dengan tempat untuk bersembunyi. Ternyata dengan bersembunyi anak-anak mendapatkan dirinya melakukan dua aktivitas dalam satu kegiatan. Melalui bersembunyi anak-anak bermain dengan orang-orang sekitarnya sekaligus mendapatkan privasinya. Hal tersebut sama dengan apa yang telah disampaikan oleh Hart dan Gillespe, ${ }^{35}$ keduanya menyatakan bahwa dengan bersembunyi anak-anak belajar perspective taking yang dimana hal tersebut sangat membantu anak-anak untuk mengembangkan dirinya saat berinteraksi dengan orang lain di masa mendatang. ${ }^{36}$ Bersembunyi selanjutnya disebut sebagai cara anak untuk mengembangkan pemaknaan dirinya dengan orang lain dengan cara memberikan kesan.

\section{Dua Jenis Tempat (Restoration and Imagination)}

Data yang terkumpul menyatakan terdapat dua kategori yang menjadi polaritas kegunaan tempat spesial bagi anak. Di satu sisi banyak anak menggunakan tempat spesial sebagai tempat yang mereka gunakan untuk beralih sejenak atau mundur sejenak dari realita (retreat) untuk memulihkan kondisi emosional mereka (restoration), sedangkan di sisi lain, anak menggunakan tempat spesial untuk bermain (play) dan mengembangkan imajinasinya (imagination). Anak-anak lebih memilih untuk bersembunyi saat keinginan mereka tidak terpenuhi atau saat mereka merasa orang disekitarnya tidak mendukung mereka atau bahkan marah pada mereka. Inilah yang membuktikan bahwa tempat spesial adalah tempat restorasi bagi anak. Keterangan orangtua subjek menegaskan fungsi retreat dan restoration dari tempat spesial anak. Beberapa orangtua menyatakan bahwa anak-anak mereka akan menuju tempattempat tertentu saat mereka marah atau dalam kesulitan. Setelah cukup waktu

35 R. Hart dan Daiute. C. “Developmental Theory and Children's Participation in Community Organizations." Social Justice 24 (1997): 3.

36 Hart, R. "Children's Experience of Place." 
untuk mengasingkan dirinya, anak-anak kembali dengan kondisi emosional yang telah berubah atau bahkan perasaan baru. Biasanya anak-anak membutuhkan waktu yang tidak terlalu lama untuk keluar dan mengubah kondisi emosionalnya, rata-rata orantua menyatakan tidak lebih dari setengah jam. Waktu yang dibutuhkan anak akan lebih singkat apabila orangtua menawarkan hal-hal yang dibutuhkan anak-anak untuk kembali dan tidak marah lagi. Seperti menawarkan makanan, mainan atau memberikan janji mengajak jalan-jalan. Temuan diatas memperluas pemahaman tentang tempat restorasi anak, bahwa anak-anak membutuhkan waktu sejenak dalam tempat yang dianggap spesial untuk memulihkan kondisi emosional mereka.

\section{Tempat Bermain dan Berimajinasi}

Di sisi lain, anak-anak seringkali menggunakan tempat spesial untuk mengembangkan imajinasi mereka, menciptakan dunia mereka dan mempercayainya. Anak sering menggunakan tempat spesial untuk bermain, membawa mainan dan mulai bermain peran dengan mainannya. Perilaku tersebut menunjukkan bahwa tempat spesial juga digunakan anak untuk berimajinasi dan memfasilitasi animisme anak-anak saat menghidupkan mainan mereka dengan imajinasi.

Bermain merupakan salah satu bagian terpenting pembentukan pengalaman anak melalui tempat spesial. Berikut adalah beberapa unsur bermain dramatis yang dilakukan anak saat di tempat spesial mereka:

Tabel 3. Jenis Permainan Simbolik Anak

\begin{tabular}{|c|l|l|}
\hline No & \multicolumn{1}{|c|}{ Unsur Bermain } & \multicolumn{1}{c|}{ Keterangan } \\
\hline 1 & $\begin{array}{l}\text { Bermain Peran/Role } \\
\text { Playing }\end{array}$ & $\begin{array}{l}\text { Anak memerankan sebuah peran seperti } \\
\text { peran ibu, bapak, guru, pahlawan dan lainnya } \\
\text { melalui gerakan dan gaya bicara. }\end{array}$ \\
\hline 2 & Make-Believe (Action) & $\begin{array}{l}\text { Anak memeragakan gerakan-gerakan tertentu } \\
\text { dalam memainkan peran. Bedanya dengan role } \\
\text { playing adalah mereka hanya memainkan satu } \\
\text { peran saja }\end{array}$ \\
\hline 3 & Make-Believe (Object) & $\begin{array}{l}\text { Anak menggunakan benda-benda untuk } \\
\text { menggantikan benda aslinya. Contoh: } \\
\text { menganggap mainan seolah-olah menjadi } \\
\text { nyata }\end{array}$ \\
\hline 4 & Make-Believe (Situation) & $\begin{array}{l}\text { Anak menciptakan situasi dan berperilaku } \\
\text { seolah-olah mereka dalam situasi tersebut. } \\
\text { Contoh: Radip mengajak temannya berlari }\end{array}$ \\
\hline
\end{tabular}




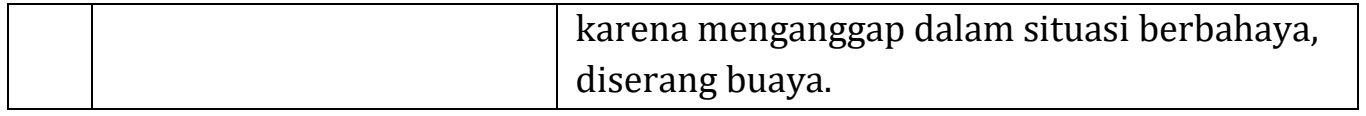

(Diadaptasi dari Trawick-Smith, 2003)

Tabel diatas menunjukkan bahwa terdapat minimal empat jenis permianan peran yang dilakukan anak-anak dalam tempat spesial mereka. Anak mulai bermain untuk memerankan sebuah peran dalam sebuah situasi, seperti menjadi ayah/ibu, guru ataupun pahlawan. Untuk meyakinkan dirinya dan juga teman mainnya anak-anak meningkatkan level permainan dengan menirukan gerakan-gerakan tertentu yang identik dengan peran mereka. contohnya gerakan menggendong anak dalam peran ibu. Beberapa atribut digunakan untuk mempertegas peran tersebut, hal ini biasa dilakukan untuk menguatkan subjek yang diperankan anak. Contohnya menggunakan kompor dan perlengkapan masak untuk menguatkan peran sebagai iu. Anak-anak juga memperkaya permaianan mereka dengan situasi yang seolah-olah nyata. Contohnya anak menyuruh teman-temannya untuk mendengarkan saat berperan sebagai guru.

\section{Otonomi dan Perkembangan Identitas}

Anak-anak mencapai otonomi spasial dan rasa privasi saat mendapatkan kontrol atas ruang tertentu. ${ }^{37}$ Kemandirian seorang anak tumbuh ditunjukkan melalui manipulasi benda-benda fisik dan ruang, hal tersebut memberikan anak rasa individualitas. ${ }^{38}$ Privasi sangat penting untuk perkembangan psikologis, dalam hal ini meningkatkan kepercayaan diri dan harga diri anak-anak otonomi individu dan identitas diri, ${ }^{39}$ dan kemampuan masa depan untuk merasakan ruang pribadi.

Tempat-tempat spesial merupakan pilihan ruang-ruang pribadi yang memainkan peran penting dalam pengembangan otonomi individu dan identitas diri. Bahkan, beberapa pihak berpendapat bahwa privasi adalah ekspresi pribadi, dan dengan demikian meningkatkan harga diri. Dalam rangka untuk mendapatkan privasi, anak-anak memiliki kebutuhan untuk mengontrol atau membuat ruang mereka sendiri. Ruang-ruang ini menciptakan sebuah tempat di mana anak-anak dapat memisahkan diri dari orang-orang dan hal-hal di lingkungan mereka.40 Di tempat-tempat spesial, anak-anak merasa aman dan nyaman untuk bekerja melalui intensi interpersonal. ${ }^{41}$ Beberapa berpendapat

\footnotetext{
37 Proshansky. "The Development of Place Identity," 27.

38 Proshansky. "The Development of Place Identity," 21-40.

39 Proshansky. "The Development of Place Identity," 21-40.

40 Piaget, J. dan Inhelder, B. The Psychology of the Child (New York: Basic Books, 1969).

${ }^{41}$ Chawla. "Childhood Place Attachments,"63-86.
} 
bahwa privasi dapat dicapai melalui beberapa derajat kontrol atas lingkungan fisik dimana hal tersebut sangat penting untuk kesehatan perkembangan psikologis anak. ${ }^{42}$

Pendapat-pendapat diatas senada dengan Erikson yang percaya bahwa melalui bermain anak-anak mengembangkan penguasaan diri mereka terhadap lingkungannya. ${ }^{43}$ Bahkan Cobb menganggap bermain peran sama halnya dengan "fingering over the environment" atau bisa disebut sebagai uji coba awal menggunakan kapasitas sensorik terhadap lingkungannya. ${ }^{44} 45$ Hal tersebut akan memperkuat organisasi sensor anak untuk menyiapkan pemaknaan terhadap lingkungan. Sama seperti penelitian sebelumnya, penelitian ini menemukan bahwa anak-anak menjadi dirinya sendiri dan mengontrol dunia imajinasinya dengan bermain sendiri ataupun berbagi ruang dengan saudara dan temantemannya. Penelitian ini juga memperluas khasanah tentang pentingnya pemberian otonomi kepada anak untuk mengontrol dan mengembangkan imajinasi mereka dalam ruang privasi yang mereka anggap spesial. Beberapa orangtua bahkan memberikan kesaksian bahwa beberapa anak mampu bertahan dalam tempat spesial mereka sampai berhari-hari sebelum bermain peran dalam tempat yang lainnya. Ini menunjukkan bahwa karakteristik anak berbeda satu dengan yang lain, juga jangan lupakan stimulus yang mereka terima untuk mengembangkan imajinasinya.

\section{Berpura-pura dan Berkembang}

Peneliti mendapati beberapa anak menceritakan hal yang berbeda saat di sekolah dan saat observasi di rumah. Beberapa diantaranya menyebutkan tempat yang sama sekali berbeda seperti saat di rumah, sedangkan beberapa yang lainnya menunjukkan tempat yang memiliki karakteristik sama namun tanpa kisah yang pernah disebutkan di sekolah. Lana menjelaskan bahwa dia memiliki tempat spesial di dapur, namun pada tahapan kedua (observasi) dia tidak menunjukkan tempat tersebut. Dia berjalan begitu saja dan mengajak peneliti menuju kamar tidurnya dan menunjukkan koleksi mainannya. Begitu juga Noval, dia menjanjikan untuk memperlihatkan sebuah lorong rahasia di belakang rumahnya. Namun saat observasi kami tidak menemukan bahwa ada

\footnotetext{
42 Proshansky. "The Development of Place Identity," 21-40.

43 Erikson. "Childhood and Society."

44 Y. Tuan. Space and Place: The perspective of experience (Minneapolis, MN: University of Minnesota Press, 1977).

${ }^{45}$ M. Mitrani. "The Role of the Physical Environment in Culture Shock," Environment \& Behavior. 29(1) (1997): 64-86.
} 
lorog dibelakang rumahnya. Saat ditanya, Noval menjawab bahwa lorong tersebut sudah ditutup agar monster tidak bisa masuk kerumahnya.

Hal-hal tersebut sangat berkaitan dengan banyaknya imajinasi yang dikembangkan oleh anak. Anak pada dasarnya memiliki beberapa dunia yang dikembangkan dalam imajinasinya. ${ }^{46}$ Oleh Karena itu, seringkali anak menjelaskan sesuatu yang berbeda pada saat yang berbeda, hal tersebut sangat berkaitan dengan kondisi mereka saat itu.

\section{Konteks Budaya}

Penelitian memfokuskan kajiannya pada eksplorasi tempat spesial anakanak usia dini yang di lakukan di Kota Malang. Beberapa penelitian sebelumnya telah menunjukkan bahwa konteks budaya sangat mempengaruhi perilaku manusia, termasuk perilaku anak-anak dalam memilih model tempat spesial mereka. ${ }^{47}$ Penelitian sebelumnya juga mengungkapkan bahwa tempat spesial anak-anak dapat mengungkapkan banyak tentang identitas social dalam konteks budaya mereka.

Perlu dicatat, bahwa penelitian ini dilakukan di Kota Malang dengan subjek yang heterogen. Heterogenitas terdiri dari struktur keluarga, ukuran rumah dan juga urutan anak dari subjek. Struktur keluarga subjek dalam penelitian ini berbedabeda, meskipun sebagian besarnya adalah keluarga kecil yang hidup sendiri. Namun beberapa diantaranya adalah keluarga yang masih hidup bersama di rumah orangtua/mertua. Beberapa diantaranya juga keluarga yang menggunakan jasa pengasuh saat pagi sampai sore hari. Ukuran rumah juga berbeda, sebagaian besar subjek masih belum memiliki kamar sendiri dan tidur bersama dengan orangtua mereka. Sebagian lagi memeiliki kamar namun tetap tidur dengan orangtua mereka. Rata-rata rumah subjek dalam penelitian ini tidak memiliki halaman depan dan belakang rumah. Yang terakhir adalah urutan anak. Subjek dalam penelitian ini sebagian besar adalah anak pertama, namun beberapa diantaranya adalah anak tengah dan anak terakhir.

\section{H. Kesimpulan}

Hasil dari penelitian ini mengisi beberapa kekosongan yang belum terjawab dalam penelitian sebelumnya, yaitu mengidentifikasi jenis tempat spesial anak dan lokasi-lokasi tempat spesial anak di rumah mereka. Hal tersebut menegaskan penelitian-penelitian sebelumnya yang telah mengidentifikasi jenis dan lokasi tempat spesial anak di sekolah Zeegers, Readicck dan Hansen-Gandy. 48

\footnotetext{
46 Hart, R. "Children's Experience of Place."

47 D. Sobel. "Children's Special Places."

48 Hart, R. "Children's Experience of Place." 
Selain mengidentifikasi jenis dan lokasi tempat spesial anak di rumah, penelitian ini juga menemukan kegiatan-kegiatan favorit yang dilakukan anak-anak saat berada pada tempat spesial mereka serta benda-benda yang biasanya mereka bawa dalam tempat spesial mereka. Lebih dari itu, peneliti juga mengeksplorasi perasaan anak-anak saat berada pada tempat-tempat spesial mereka dengan bantuan wawancara dengan orangtua mereka.

Secara keseluruhan, penelitian ini menunjukkan bahwa anak-anak memiliki banyak jenis tempat spesial yang mereka gunakan untuk memenuhi beberapa tujuan dalam hidup mereka. Anak-anak memiliki banyak tempat spesial di sekitar rumah tempat tinggal mereka. Studi terdahulu menyebutkan bahwa tempat tidur adalah tempat spesial yang banyak ditunjuk oleh anak-anak usia dini. ${ }^{49}$ Namun penelitian ini menemukan bahwa tempat yang paling banyak ditunjuk anak-anak adalah di balik pintu dan di bawah tempat tidur.

Penelitian ini juga menunjukkan bahwa anak-anak memiliki banyak tempat spesial di rumah mereka. Hal tersebut sangat bergantung pada kondisi dan kebutuhan mereka akan tempat tersebut. Contohnya anak memilih berada di bawah tempat tidur saat dia marah. Pemilihan bawah tempat tidur ini sangat berhubungan dengan keinginan anak untuk bersembunyi dari orangtua. Terdapat juga anak yang memilih lokasi antara kursi dan meja dengan atribut mirip tenda saat mereka butuh untuk bermain dengan teman yang bertamu dating kerumahnya.

Temuan dari penelitian ini yang lain adalah penggunaan tempat spesial bagi anak. Anak-anak menggunakan tempat spesial untuk bersembunyi, bermain dan juga untuk sekedar menghindar dari orangtua saat mereka merasa terancam. Temuan tersebut mempertegas hasil penelitian-penelitian terdahulu. ${ }^{50}$ 51

Penelitian ini juga menemukan bahwa anak-anak menggunakan tempat spesial mereka untuk berhenti sejenak (retreat) untuk mengontrol emosi mereka. Saat mereka mulai mengontrol emosi, mereka juga melakukan permainan dengan menggunakan imajinasi mereka dengan bermain peran dan bermain situasi. Tempat spesial digunakan anak untuk lokasi mereka memerankan peran dengan dibantu dengan beberapaa mainan dan juga skema drama sederhana yang seolah-olah mereka memerankan salah satu figur dalam kehidupan nyata seperti figure ayah/ibu, guru dan pahlawan.

49 Marton, F. "Phenomenography - A Research approach to investigating different understanding of reality," J Thought, 21 (3), (1986): 28-49.

50 D. Sobel. "Children's Special Places."

${ }^{51}$ Hart, R. "Children's Experience of Place." 
Hal terakhir yang mempertegas teori dari Erikson adalah bahwa tempat spesial digunakan anak untuk mengembangkan rasa otonomi mereka dan juga sekaligus perkembangan identitas kepribadian mereka.52 Penelitian-penelitian lain yang serupa juga menemukan hal sama tentang perkembangan otonomi. ${ }^{53}$ Anak-anak usia dini tidak hanya memilih lokasi untuk tempat spesial mereka, mereka juga menerapkan aturan untuk orang lain (terutama orangtua) untuk mengakses tempat tersebut. Oleh Karena itu kebanyakan tempat spesial terdapat pada lokasi yang tidak luas, hal tersebut bukan Karena Karena ukuran anak-anak yang kecil, namun juga sekaligus sebagai aturan untuk membatasi orang dewasa masuk dalam lokasi tersebut.

Tempat spesial sangat penting untuk perkembangan emosional anak mengingat mereka mulai mengatur segala sesuatu sesuai keinginan mereka. Anak mendapatkan kebebasan mengekspresikan keinginan mereka untuk menciptakan, membuat, berpura-pura, dan mengambil resiko. Erikson menyatakan bahwa jika anak-anak tidak medapatkan privasi akan tempat spesial mereka, maka mereka akan mengembangkan perasaan ragu-ragu dan malu. ${ }^{54}$ Oleh karena itu, sangatlah penting bahwa orang tua, guru, dan pengasuh lainnya memahami pentingnya tempat spesial bagi anak untuk menyediakan ruang bagi mereka mengembangkan rasa otonomi.

Tempat dan kondisi penelitian juga sangat memperngaruhi pilihan anak untuk bermain memilih tempat spesial mereka di lokasi dalam rumah maupun luar rumah. Anak-anak dalam penelitian ini cenderung memilih lokasi dalam ruangan mengingat lokasi rumah kebanyakan subjek penelitian tidak memungkinkan anak untuk memilih lokasi luar ruangan. Kebanyakan rumah subjek penelitian tidaklah luas dan tidaklah memiliki lokasi luar ruangan seperti taman di depan rumah dan di belakang rumah. Inilah yang memiliki kemungkinan terbesar mengapa anak-anak lebih sering bermain dalam lokasi tempat spesial yang berada dalam ruangan rumah.

52 Erikson. "Childhood and Society."

53 D. Sobel. "Children's Special Places."

${ }^{54}$ Erikson. "Childhood and Society." 


\section{Referensi}

Altman, I. dan Low, S.M. Place Attachment (New York: Plenum Press, 1992).

Arikunto, S. Prosedur Penelitian: Suatu Pendekatan Prakter (Jakarta: Rineka Cipta, 2006).

Brey, P. "Space-shaping technologies and the geographical disembedding of place" In A. Light and J.M. Smith (Ed.), Philosophy and geography III: Philosophies of place (Lanham, MD: Rowman \& Littlefield, 1998), 239263.

Chawla, L. “Ecstatic Places. Children's Environments Quarterly" 7(4) (1990): 1823.

Chawla, L. “Childhood Place Attachments," In Altman, I. and S. Low, ed. Place Attachment (New York: Plenum, 1992), 63-86.

Ellis, J. "The Significance of Place in the Curriculum of Children's Everyday Lives.” Taboo: The Journal of Culture and Education 8(1) (2004): 23-42.

Erikson, Erik H. Childhood and Society (New York: Norton, 1950).

Giuliani, M. V. “Theory of attachment and place attachment,” In M. Bonnes, T. Lee, \& M. Bonaiuto (Ed.), Psychological theories for environmental issues (Aldershot: Ashgate, 2003), 137-170.

Green, C. “A Place of My Own: Exploring Preschool Children's Special Places in the Home Environment," Children, Youth and Environments 21(2), (2011).

Hart, R. Children's Experience of Place (New York: Irvington Publishers, 1979).

Hart, R. dan Daiute. C. "Developmental Theory and Children's Participation in Community Organizations." Social Justice 24 (1997): 3.

Hidalgo, M.C. dan Hernandez, B. "Place Attachment: Conceptual and Empirical Questions." Journal of Environmental Psychology 21(2001): 273-281.

Hummon, D. M. "Community Attachment: Local Sentiment and Sense Of Place.” In: Altman, I. and Low, S., ed. Place Attachment (New York, NY: Plenium Press, 1992), 314.

Hunter, A. "Persistence of Local Sentiments In Mass Society," In: Street, D., ed. Handbook of Contemporary Urban Life (San Francisco, CA: Jossey-Bass, 1978), 741.

Marton, F. "Phenomenography - Describing Conceptions of the World Around Us," Instructional Science, 10, (1981): 177-200.

Marton, F. "Phenomenography - A Research approach to investigating different understanding of reality," J Thought, 21 (3), (1986): 28-49.

Merriam, S.B. Qualitative Research in Practice: Examples for Discussion and Analysis (San Francisco: Jossey-Bass, 2002).

Mitrani, M. "The Role of the Physical Environment in Culture Shock," Environment \& Behavior. 29(1) (1997): 64-86. 
Piaget, J. dan Inhelder, B. The Psychology of the Child (New York: Basic Books, 1969).

Proshansky, H. M. dan Fabian, A.K. "The Development of Place Identity in the Child." In Weinstein, Carol S. and Thomas G. David, ed. Spaces for Children: The Built Environment and Child Development (New York: Plenum Press, 1987), 21-40.

Riley, R.B. “Attachment to the Ordinary Landscape.” In I. Altman and S.M. Low, ed. Place Attachment (New York: Plenum Press, 1992), 13-35.

Saldana, J. The Coding Manual for Qualitative Researchers (Los Angeles: Sage, 2009).

Smith, J. M., Light, A., \& Roberts, D. "Introduction: Philosophies and geographies of place," In A. Light \& J. M. Smith (Ed.), Philosophy and geography III: Philosophies of place (Lanham, MD: Rowman \& Littlefield, 1-13), 1-13.

Sobel, D. Children's Special Places: Exploring the Role of Forts, Dens, and Bush Homes in Middle Childhoo. (Detroit: Wayne State University, 2002).

Strauss, A., dan Corbin, J. Basics of Qualitative Research: grounded theory procedures and techniques (USA: Sage Publications, 1990).

Sturm, B. W. "Imaginary 'Geographies' of Childhood: School Library Media Centers as Secret Spaces." Knowledge Quest Maps: The Why of Where 36(4) (2007): 46-53.

Tuan, Y. Space and Place: The perspective of experience (Minneapolis, MN: University of Minnesota Press, 1977).

Tunner, J. “Special Place: Place Attachment and Children's Happiness," Primary Geographer (2009): 1-8.

Uljens, M. “On the philosophical foundation of phenomenography," In G. Dall'Alba \& B. Hasselgren (Ed.), Reflections on Phenomenography (Goteborg: Acta Universitatis Gothenburgensis, 1996), 105-130. 